\title{
COVID-19 outbreak: Water loss during handwashing, need more concern?
}

\author{
Abu Sayeed ${ }^{1}$, Satyajit Kunduㄹ Md. Hasan Al Banna ${ }^{3}$, Md. Nazmul Hassan ${ }^{4}$
}

\section{AFFILIATION}

1 Department of Post-Harvest Technology and Marketing, Patuakhali Science and Technology University, Patuakhali, Bangladesh

2 Department of Biochemistry and Food Analysis, Patuakhali Science and Technology University, Patuakhali, Bangladesh

3 Department of Food Microbiology, Patuakhali Science and Technology University, Patuakhali, Bangladesh

4 Department of Environmental Sanitation, Patuakhali Science and Technology University, Patuakhali, Bangladesh

CORRESPONDENCE TO

Abu Sayeed. Department of Post-Harvest Technology and Marketing, Patuakhali Science and Technology University, Patuakhali, 8602,

Popul. Med. 2020;2(October):34
Bangladesh. E-mail: shuvo.nfs.pstu@gmail.com ORCID ID: https://orcid. org/0000-0003-0745-1755

\section{KEYWORDS}

water loss, COVID-19, handwashing

Received: 25 August 2020, Revised: 4 September 2020,

Accepted: 23 September 2020

\section{Dear Editor,}

The novel coronavirus disease (COVID-19), caused by the severe acute respiratory syndrome coronavirus 2 (SARSCoV-2), is a highly transmissible human respiratory disease. This zoonotic virus is transmitted by droplets, fecal-oral route, and direct contact ${ }^{1}$. To date (14 August 2020), 21 million people across 215 countries and territories have been infected by COVID-19, and more than 0.76 million people have died ${ }^{2}$. One of the best precautions to minimize the risk of being infected or spreading COVID-19 is to frequently wash hands on both sides by scrubbing with soap for at least 20 seconds followed by rinsing with clean water ${ }^{3}$.

A 15 to 20-second handwash would use about two litres of water if the faucet is open, or one litre when the tap is off while the soap is scrubbed ${ }^{4}$. It is assumed that each person would use around 10 to 20 litres of water every day if he or she cleans his or her hands at least ten times per day to prevent COVID-19 infection ${ }^{4}$. A family of five members would, therefore, need about 50 to 100 litres of water every day for handwashing, resulting in an increased water demand by 20 to $25 \%$ amid the COVID-19 pandemic ${ }^{4}$. Such a sudden increase in water demand could lead to severe water shortages, especially in areas/countries where supply is already strained. For instance, a water sector department of Jordan recently stated that when the government ordered their people to stay home as part of the home-quarantine measure, the demand of water rose by $40 \%{ }^{5}$. The water demand for clean water increased during the outbreak of Ebola in West Africa in 2014-2016 in order to prevent the disease and treat the infected people ${ }^{5}$.

Around 2 billion people living worldwide are experiencing water stress, which is indeed soaring day-by-day ${ }^{6}$. This is especially evident in small and medium-sized countries in the world, which might be attributed to several reasons: 1 ) limited water in those areas, 2) water loss due to dryness or climate change, 3) water being unsuitable for use due to contamination of local water supplies, and 4) nearest water source may be far from home. At the same time, the global water demand is rising at about $1 \%$ per year, and the demand has been unexpectedly increased as a consequence of the COVID-19 pandemic ${ }^{7}$ and predicted to worsen with time. Such an unanticipated global demand for water would bring enormous pressure on limited water resources exacerbating the existing insufficiency in the water supply. Thus, some options include raising awareness about closing taps or using sensor taps that turn off automatically while scrubbing hands with the soap. Alternatively, the use of alcohol-based hand gel could be a reasonable solution to prevent water loss, if the cost is low.

\section{REFERENCES}

1. World Health Organization. Emerging Respiratory Viruses, Including COVID-19: Methods for Detection, Prevention, Response, and Control. https://openwho.org/courses/ introduction-to-ncov. Accessed September 4, 2020.

2. Worldometer. Bangladesh Coronavirus Cases. Worldometer. https://www.worldometers.info/coronavirus/country/ bangladesh/. Accessed September 4, 2020.

3. UNICEF. Everything you need to know about washing your hands to protect against coronavirus (COVID-19). https:// www.unicef.org/coronavirus/everything-you-need-knowabout-washing-your-hands-protect-against-coronavirus- 
covid-19. Published March 13, 2020. Revised September 17, 2020. Accessed September 4, 2020.

4. Rohilla SK. COVID-19 outbreak: More hand washing can increase India's water woes. https://www.downtoearth.org. in/blog/water/covid-19-outbreak-more-hand-washing-canincrease-india-s-water-woes-69900. Revised March 21, 2020. Accessed September 4, 2020.

5. Al-Masri RA. Coronavirus: what might more hand washing mean in countries with water shortages?. The Conversation. https://theconversation.com/coronavirus-what-mightmore-hand-washing-mean-in-countries-with-watershortages-134625. Published March 30, 2020. Accessed September 4, 2020.

6. Water Scarcity Clock. World Data Lab. https://worldwaterio/. Accessed September 4, 2020.

7. Cooper R. Water security beyond Covid-19. Governance and Social Development Resource Centre. https://gsdrc.org/ publications/water-security-beyond-covid-19. Published May, 2020. Accessed September 4, 2020.

\section{ACKNOWLEDGEMENT}

The authors express their gratitude to Saiful Islam and Tanmoy Roy Tusher for checking the manuscript consistency and correcting the language.

\section{CONFLICTS OF INTEREST}

The authors have completed and submitted the ICMJE Form for Disclosure of Potential Conflicts of Interest and none was reported.
FUNDING

There was no source of funding for this research.

PROVENANCE AND PEER REVIEW

Not commissioned; internally peer reviewed. 